(C) 2020

\title{
Dynamics of labile organic compounds of light-gray forest surface gleyed soils at long-term agrogenic influence
}

\author{
Partyka T. ${ }^{1}$, Olifir Y. ${ }^{2}$, Habryiel A. ${ }^{3}$, Havryshko $0 .^{4}$ \\ Institute of Agriculture of the Carpathian region of NAAS \\ 5 Hrushevskoho Str., Obroshyne vill., Pustomyty district, Lviv oblast, 81115, Ukraine \\ e-mail: ${ }^{1}$ tetyana.partyka@gmail.com, ${ }^{2}$ olifir.yura@gmail.com, ${ }^{4}$ havryshko0@gmail.com \\ ORCID: ${ }^{1} 0000-0001-7912-5292,{ }^{2} 0000-0002-7920-1854,{ }^{3} 0000-0003-4379-3269,{ }^{4} 0000-0002-5458-0691$
}

Goal. To study dynamics of labile organic compounds of light gray forest surface-gleyed soil during vegetation of spring barley depending on long-term application of different fertilizer systems and periodic liming. Methods. Field studies, physical, chemical and comparative analytical methods. Results. The content of labile humus in the arable layer of acidic light gray forest soil isn't high and does not exceed $0.73 \%$. Long-term use of mineral fertilizer systems causes the lowest content of labile humus compounds, which during the growing season does not exceed $0.50 \%$. Application of organo-mineral fertilizer systems with introduction of one norm of mineral fertilizers $\left(\mathrm{N}_{65} \mathrm{P}_{68} \mathrm{~K}_{68}\right), 10 \mathrm{t} /$ ha of manure per hectare of crop rotation area both with the background of liming by a dose of $\mathrm{CaCO}_{3}$ calculated according to hydrolytic acidity and to acid-base buffering capacity provides practically the same content of labile $(0.49-0.60 \%)$ and water-soluble organic matter $(0.025-0.042 \%)$ during the growing season of spring barley. The absence of fertilizer during the growing season of spring barley caused the lowest values of water-soluble organic matter $(0.013-0.02 \%)$ in the control variant. Conclusions. The supply of light gray forest surface-gleyed soils with labile forms of organic matter during prolonged agrogenic influence varies depending on the fertilizer and use.

Key words: soil organic matter, water-soluble humus, labile humus, fertilizers, liming, manure, spring barley.

DOI: https://doi.org/10.31073/agrovisnyk202012-02

Soil organic matter and its component humus ensure stability of soil system and is among the most important diagnostic features of soil functioning [1]. The study of the nature and direction of changes in organic matter content is especially relevant for the gray forest soils of the Carpathian region, which are characterized by low levels of natural fertility and low humus content.

When assessing the quality of soil organic matter, its mobile compounds are important. They are involved in formation of soil structure and other properties, largely determine the dynamics of modern soil processes and are material for the creation of stable humic substances [2, 3].

A significant role in soil formation and soil fertility is also played by water-soluble organic matter - a complex mixture of organic compounds formed from plant residues, microbial biomass and root exudates. Despite low absolute content (1-5\% of the total organic carbon content), it determines soil microbial activity, actively participates in soil processes, is the most accessible substrate and source material for the formation of all groups of stable humic substances, activates the mobilization of nutrients and enhances their migration ability [4-6].

Due to their structure labile components of organic matter are primarily affected by natural and anthropogenic factors. Their content in the arable layer is determined foremost by the doses of fertilizers, amount of crop residues and tillage [3]. However, impact share of these measures is difficult to estimate, because effect mechanism of agronomic measures may be different in different soils [7-9].

Therefore, the study of the content dynamics of labile and water-soluble humus during the growing season of agricultural crops is of great importance and allows, based on the established patterns of its change, to adjust the level of fertilization, improve existing agricultural practices to ensure the appropriate level of soil fertility and health $[10,11]$.

Goal. To study dynamics of labile organic compounds of light gray forest surface-gleyed soil during vegetation of spring barley depending on long-term application of different fertilizer systems and periodic liming.

Research methodology. The studies were carried out during 2017-2019 on the classic long-term stationary experience of the Institute of Agriculture of the Carpathian Region of NAAS, established in 1956 on a light gray forest surface gleyed soil with different doses and ratios of mineral fertilizers, manure and lime.

The stationary experiment is placed in space on 3 fields, each of which has 18 variants in 3 repetitions. The arrangement of the variants is single-tiered, consistent. The total plot area is $168 \mathrm{~m}^{2}$, the accounting area is $100 \mathrm{~m}^{2}$. Four-field crop rotation with the following crops: corn for silage, spring barley with sowing of meadow clover, meadow clover, winter wheat. The soil of the experimental site is light gray forest surfacegleyed with coarse-grained light loam on loess-like sediments.

Research work was carried out in the following variants: absolute control (without fertilizer, var. 1); application of only organic (10 t/ha of crop rotation area, var. 3) and mineral fertilizers $\left(\mathrm{N}_{65} \mathrm{P}_{68} \mathrm{~K}_{68}\right.$, var. 15); 
liming with doses calculated according to hydrolytic acidity and acid-base buffering capacity in organomineral (10 t/ha manure $+N_{65} P_{68} K_{68}$, var. 7 and 8) and mineral fertilizer systems $\left(N_{105} P_{101} K_{101}\right.$, var. 17 and 18).

Semi-precipitated cattle manure on straw bedding, ammonium nitrate $(34.5 \%)$, granulated superphosphate (19.5\%), potassium salt (40\%), nitroamophos (NPK $16 \%$ ) were used in the experiment. Manure (40-60 t/ha) was introduced under corn. Phosphorus-potassium fertilizers were introduced in the fall, nitrogen - under pre-sowing cultivation. Liming was carried out before the start of IX rotation. Limestone flour $\left(93.5 \% \mathrm{CaCO}_{3}\right)$ was used as the limestone fertilizer. Cultivation technology is generally accepted for the conditions of the Western Forest-Steppe zone of Ukraine.

Soil samples were taken and prepared for analysis in accordance with DSTU ISO 11464-2001. Agrochemical analyses of the soil were performed according to the following methods: labile organic matter by M. A. Egorov method with its subsequent oxidation by I. V. Tyurin method in the modification of B. A. Nikitin (DSTU 4732-2007), water-soluble organic matter according to the generally accepted method with the end according to I. V. Tyurin method in the modification of B. A. Nikitin (DSTU 4731-2007) [12, 13]. The results of laboratory studies were statistically processed according to conventional methods of Ye. A. Dmitriev and B. A. Dospekhov [14, 15].

Results. On the basis of studies carried out in the arable soil layer $(0-20 \mathrm{~cm})$ under the second crop of $X$ crop rotation - spring barley, it was found that the content of labile humus varies depending on the fertilizer system and development phase.

Thus, in the tillering phase of spring barley in control variant and with prolonged application of only mineral fertilizers, content of labile humus is 0.50 and $0.58 \%$ respectively (Fig. 1). Content of labile humus in these variants remained quite high ( 0.54 and $0.64 \%$ ) compared to other fertilizer systems in the phase of full ripeness before harvesting of spring barley. The increase in the content of mobile humus compounds in control and variants with intensive mineral fertilizer is probably associated with the low use of nutrients by barley plants due to low yields under conditions of high acidity of the soil solution $\left(\mathrm{pH}_{\mathrm{KCl}} 4.51\right.$ and 4.24 respectively). Application of only mineral fertilizers usually increases the number of the most mobile, unprotected organic compounds. Introduction of mineral fertilizers increases the mineralization of soil organic matter. The resulting compounds usually do not form complex organic substances associated with mineral particles $[16,17]$.

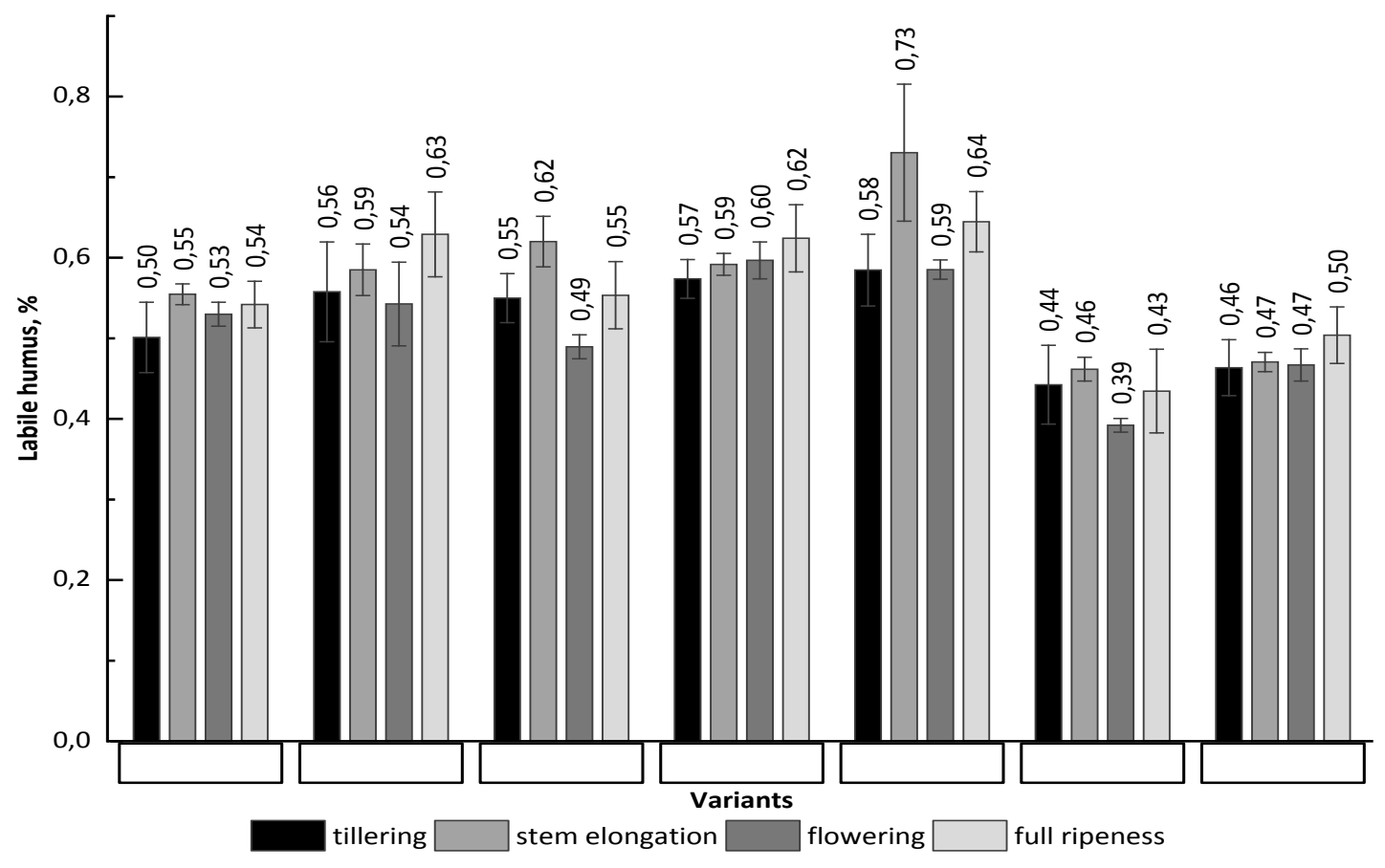

Fig. 1. Dynamics of labile humus of the arable layer of light gray forest surface-gleyed soil under spring barley

At the same time, manure application provides the supply of various organic carbon compounds. In the variant of the organic fertilizer system with the application of $40 \mathrm{t} / \mathrm{ha}$ of manure under the first crop of crop rotation, the content of labile compounds in the tillering phase is $0.56 \%$. Before harvesting in the phase of full ripeness it increases to $0.63 \%$. Also, due to organic fertilization, the root mass of plants increases, which, after harvesting, provides a constant supply of substrate for mineralization.

When applying the same doses of manure and mineral fertilizers both with the background of liming with a dose of $\mathrm{CaCO}_{3}$ calculated according to hydrolytic acidity (var. 7) and acid-base buffering capacity (var. 8), the content of labile humus under spring barley in the tillering phase is almost the same and is 0.55 and 0.57 
$\%$ respectively. In the later phases of the growing season, the level of labile humus compounds in the organo-mineral fertilizer system with optimal dose of lime remains quite high $-0.60-0.62 \%$. And in a similar fertilizer system with liming according to hydrolytic acidity, the content of labile compounds is reduced to $0.49-0.55 \%$ due to more intensive use by plants. In mineral fertilizer systems the content of labile humus compounds is lower and does not exceed $0.50 \%$ during growing season.

Studies have shown that the lowest amount of water-soluble humus during growing season of spring barley $(0.016-0.021 \%)$ was observed in control variants without fertilizers (Fig. 2). This is probably due to the predominance of mobile fulvic acids of $1+1$ a fraction in the humus composition due to the high acidity of the soil solution. Under conditions of periodic washing water regime these fractions migrate rapidly and are washed out of the arable layer. It should also be noted that in these variants meadow clover was very sparse because of high acidity of the soil solution. Therefore, the influence of organic residues on the processes of water-soluble humus accumulation and humus formation is generally insignificant.

In the variant of intensive mineral fertilization, the content of water-soluble humus was lower in comparison with organo-mineral and mineral fertilizer systems with the background of liming and amounted to $0.029-0.035 \%$. The reason for low content of water-soluble humus in the variants of long-term use of only the mineral fertilizer system is the insignificant amount of plant residues of cultivated crops, used by the microflora as a nutritious and energetic material.

When applying organic fertilizer system with the introduction of $40 \mathrm{t} / \mathrm{ha}$ of manure per rotation, the level of water-soluble humus increases to $0.024-0.042 \%$. This is due to the fact that cattle manure is largely represented by water-soluble and labile humic compounds - intermediate products of transformation of organic matter of manure [4].

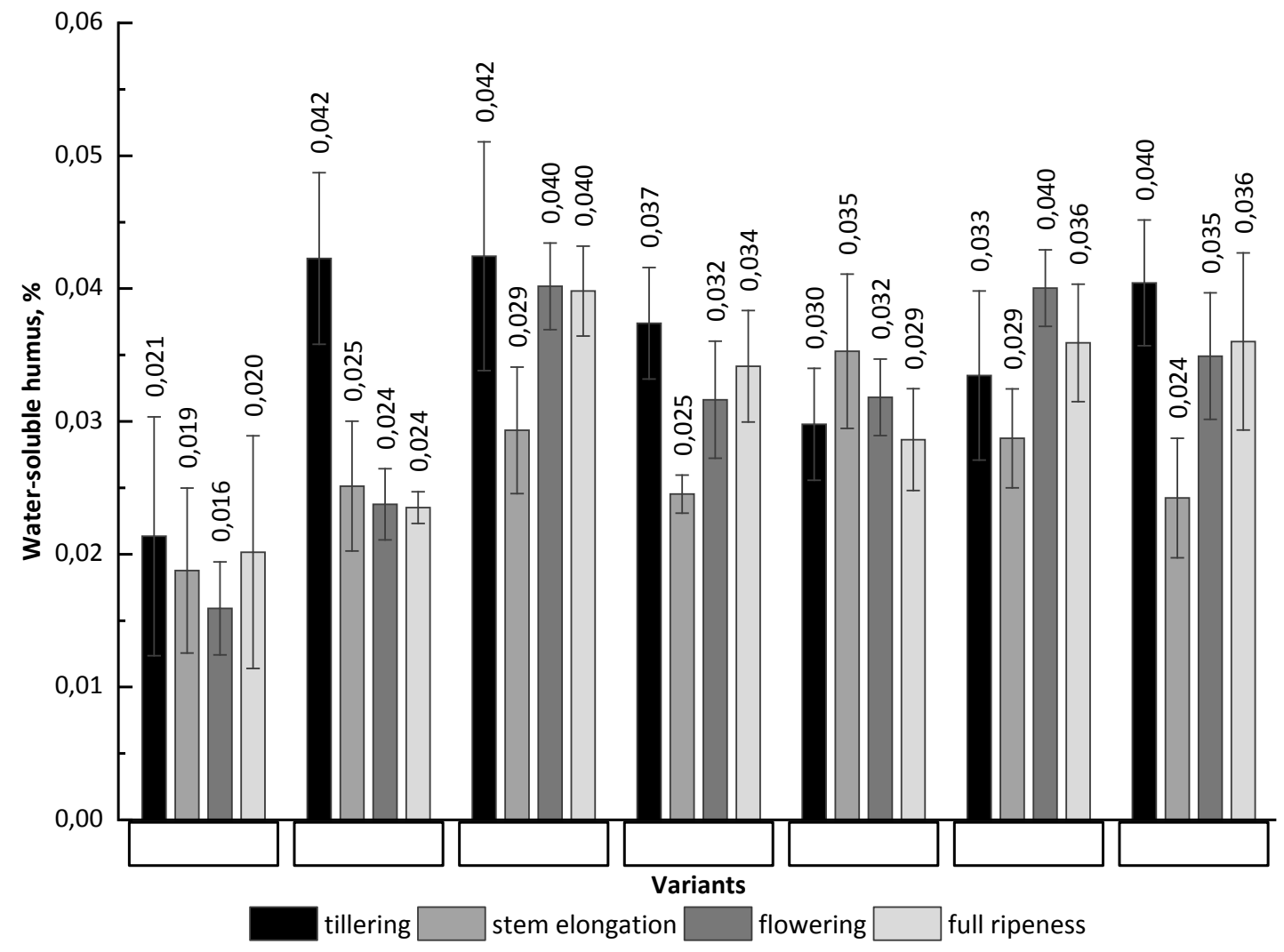

Fig. 2. Dynamics of water-soluble humus of the arable layer of light gray forest surface-gleyed soil under spring barley

In the variants of combined application of organic, mineral fertilizers and lime an increase in the level of water-soluble humus was noted during the period of active growth and development of spring barley plants in comparison with the control without fertilizers. Thus, the application of organo-mineral fertilizer system with introduction of $\mathrm{N}_{65} \mathrm{P}_{68} \mathrm{~K}_{68}, 10 \mathrm{t}$ of manure per 1 ha of crop rotation area with the background of lime application according to hydrolytic acidity provided an increase in water-soluble humus during the growing season of spring barley to $0.029-0.042 \%$. This fertilizer system, but with the background of the introduction of optimal rate of lime in accordance with acid-base buffering capacity contributed to obtaining slightly lower values of water-soluble compounds $-0.025-0.037 \%$.

The application of high rates of mineral fertilizers with the background of liming with a dose of $\mathrm{CaCO}_{3}$, calculated according to hydrolytic acidity did not contribute to increase in the level of water-soluble humus compounds during the growing season, compared with the application of a similar dose of lime calculated in accordance with acid-base buffering capacity. 


\section{Conclusions}

Prolonged application of organo-mineral fertilizer systems on acidic light gray forest surface-gleyed soil with introduction of $N_{65} P_{68} K_{68}, 10 t$ of manure per hectare of crop rotation area, both with the background of liming by $\mathrm{CaCO}_{3}$ dose calculated according to hydrolytic acidity and acid-base buffering capacity provides higher content of labile humus under spring barley than similar mineral fertilizer systems.

The lowest amount of water-soluble humus during the growing season of spring barley (0.016-0.021\%) was observed in control variant without fertilizers. This indicates that at high acidity of the soil solution the humus composition of acidic light gray forest surface-gleyed soil in the first stages of humus formation is dominated by the accumulation of mobile fulvic acids, which in conditions of periodic washing water regime are capable of rapid migration and leaching out of the arable layer.

\section{References}

1. Skrylnyk, Ye. V., Hetmanenko, V. A., \& Kutova, A. M. (2018). Rozrakhunkovi modeli balansu humusu yak pokaznyka ahroekolohichnoi stabilnosti orhanizatsii zemlekorystuvannia [Estimation models of humus balance as an indicator of agroecological stability of land management organization]. Scientific horizons, 7-8 (70), 139-144. [in Ukrainian].

2. Lykov, A. M., Chernishov, V. A., \& Bonichan, B. P. (1981). Otsenka gumusa pochv po kharakteristike ego labilnoy chasti [Assessment of soil humus by the characteristics of its labile part]. Izvestiya of TAA, 5, 65-70. [in Russian].

3. Zavyalova, N. Ye., \& Yamaltdinova, V. R. (2010). Vliyanie dlitelnogo primeneniya sistem udobreniya na soderzhanie labilnogo organicheskogo veshchestva dernovo-melkopodzolistoy tyazhelosuglinistoy pochvy [Influence of long-term use of fertilization systems on the content of labile organic matter in soddy-fine podzolic heavy loamy soil]. Agrarian Bulletin of the Urals, 4, 76-78. [in Russian].

4. Titova, V. I., Artemeva, Z. S., \& Arkhangelskaya, A. M. (2013). Agrogennaya transformatsiya organicheskogo veshchestva svetlo-seroy lesnoy legkosuglinistoy pochvy (po issledovaniyam $v$ dlitelnom opyte) [Agrogenic transformation of organic matter in light gray forest light loamy soil (according to studies in a long-term experiment)]. Izvestiya of TAA, 3, 18-30. [in Russian].

5. Lykov, A. M. (1982). Vosproizvodstvo plodorodiya pochv $v$ Nechernozemnoy zone [Reproduction of soil fertility in the Non-Chernozem zone]. Moscow: Rosselkhozizdat. [in Russian].

6. Hamkalo, Z., \& Bedernichek, T. (2014). Total, cold and hot water extractable organic carbon in soil profile: impact of land-use change. Zemdirbyste-Agriculture, 101 (2), 125-132. doi: 10.13080/za.2014.101.016

7. Shrestha, B. M., Singh, B. R., Forte, C., \& Certini, G. (2015). Long-term effects of tillage, nutrient application and crop rotation on soil organic matter quality assessed by NMR spectroscopy. Soil Use and Management, 31 (3), 358-366. doi: 10.1111/sum. 12198

8. Šimanský, V., Juriga, M., Jonczak, J., Uzarowicz, Ł., \& Stępień, W. (2019). How relationships between soil organic matter parameters and soil structure characteristics are affected by the long-term fertilization of a sandy soil. Geoderma, 342, 75-84. doi: 10.1016/j.geoderma.2019.02.020

9. Chantigny, M. H. (2003). Dissolved and water-extractable organic matter in soils: a review on the influence of land use and management practices. Geoderma, 113 (3-4), 357-380. doi: 10.1016/s00167061(02)00370-1

10. Baliuk, S. A., Nosko, B. S., \& Skrylnyk, Ye. V. (2016). Suchasni problemy biolohichnoi dehradatsii chornozemiv i sposoby zberezhennia yikh rodiuchosti [Modern problems of biological degradation of black earth and ways of preserving their fertility]. Bulletin of Agricultural Science, 1, 11-17. doi: 10.31073/agrovisnyk201601-02

11. Awale, R., Emeson, M. A., \& Machado, S. (2017). Soil organic carbon pools as early indicators for soil organic matter stock changes under different tillage practices in Inland Pacific Northwest. Front. Ecol. Evol., 5, Article 96. doi: 10.3389/fevo.2017.00096

12. Arinushkina, Ye. V. (1970). Rukovodstvo po khimicheskomu analizu pochv [Soil chemical analysis guide]. Moscow: Izdatelstvo MGU. [in Russian].

13. Kyrylchuk, A. A., \& Bonishko, O. S. (2011). Khimiia gruntiv. Osnovy teorii i praktykum [Soil chemistry. Fundamentals of theory and practice.]. Lviv: LNU imeni Ivana Franka. [in Ukrainian].

14. Dmitriev, Ye. A. (1972). Matematicheskaya statistika $v$ pochvovedenii [Mathematical statistics in soil science]. Moscow: Izdatelstvo MGU. [in Russian].

15. Dospekhov, B. A. (1985). Metodika polevogo opyta (s osnovami statisticheskoy obrabotki rezultatov issledovaniy) [Field experiment technique (with the basics of statistical processing of research results)]. Moscow: Agropromizdat. [in Russian].

16. Tong, X., Xu, M., Wang, X., Bhattacharyya, R., Zhang, W., \& Cong, R. (2014). Long-term fertilization effects on organic carbon fractions in a red soil of China. CATENA, 113, 251-259. doi: 10.1016/j.catena.2013.08.005

17. Li, J., Ramirez, G. H., Kiani, M., Quideau, S., Smith, E., Janzen, H., Larney, F., \& Puurveen, D. (2018). Soil organic matter dynamics in long-term temperate agroecosystems: rotation and nutrient addition effects. Canadian Journal of Soil Science. 98(2), 232-245. doi: 10.1139/cjss-2017-0127 